\title{
STUDIO INOVASI DAN KREATIF KERAJINAN KAYU
}

\author{
Joanne Triani ${ }^{1)}$, Mieke Choandi ${ }^{2)}$ \\ 1)Program Studi S1 Arsitektur, Fakultas Teknik, Universitas Tarumanagara, djoanneth@gmail.com \\ 2) Program Studi S1 Arsitektur, Fakultas Teknik, Universitas Tarumanagara, mieke@stu.untar.ac.id
}

\begin{abstract}
Abstrak
Studio kreatif dan inovasi kerajinan kayu merupakan wadah bagi pengrajin ataupun peminat ilmu dan keahlian dalam proses kerajinan, khususnya material kayu. Melalui empat program yaitu Experience, Explore \& Learn, Develop, dan Community membentuk sebuah studio yang menyediakan sumber daya, fasilitas, pengetahuan, serta sebuah komunitas untuk berkarya melalui produk kerajinan kreatif berkelanjutan, dan mendorong pertumbuhan ekonomi kreatif khususnya kerajinan kayu. Latar belakang hadirnya studio ini, karena potensi sumber daya alam hingga sumber daya kreatif yang dimiliki di Indonesia. Generasi milinial dinilai lebih kreatif daripada generasi sebelumnya, ditandai dengan ekonomi kreatif baru diberbagai bidang. Ekonomi kreatif kerajinan merupakan salah satu bidang yang menyumbang perekonomian terbesar bagi negara. Kerajinan kayu memiliki potensi yang besar, namun pertumbuhannya mengalami stagnasi. Terhambatnya pertumbuhan diakibatkan kesulitan dan terbatasnya perpindahan ilmu ke generasi muda. Untuk itu wadah komunitas ini yang dapat mengenalkan ekonomi kreatif kepada millenial, agar generasi ini dapat terlibat pengalaman dan kesempatan bertemu sesama peminat ketrampilan kerajinan. Melalui riset terhadap generasi millenial, terdapat keinginan pada generasi ini untuk terlibat pengalaman. Perilaku ini dapat dimanfaatkan untuk menawarkan suatu produk kerajinan dengan penambahan pengalaman dan cerita didalam produk yang dapat menarik minat generasi millennial. Berlokasi di Kemang, Jakarta Selatan yang dikenal sebagai kawasan berkembang ke arah artpreneur, ditandakan banyaknya art store, galeri, dan lain-lain. Studio ini menjadi wadah untuk mendapatkan pengalaman dan menggali potensi dibidang ekonomi kreatif bagi pemula. Sedangkan untuk pelaku ekonomi kreatif dapat memperdalam potensi dan berbagi ilmu dalam proses kreatif, serta mendapat kesempatan berkolaborasi dan memasarkan hasil produk ke lingkup yang lebih luas.
\end{abstract}

Kata kunci: ekonomi kreatif; generasi milenial; kreatif; kerajinan kayu; pengalaman

\begin{abstract}
Woodcrafts Innovation and Creative Studio are a place for craftsmen or enthusiasts of craftsmanship and process, especially wood. With four main programs: Experience, Explore \& Learn, Develop, and Community, it's expected to become a space for providing resources, facilities, knowledge and forming a community for people to work and create a variety of local products, as well as maintaining and contributing to creative economic growth. The background of this studio, because of the potential of natural resources and creative resources. Millennials' behavior differs from those of the previous generation, whereas millennials are perceived to be more creative, giving birth to many potentials in creative economy industry. Craft is one of the three industries who constitute the most contributions to the creative economy, namely woodcraft. Although potential, it's growth has shown to be stagnated, due to the difficulty to transfer of knowledge to the younger generation. For this reason, it's necessary to provide a space that can introduce and become a forum to ensure the development of creative economy. Based on the results of some researches conducted on millennials, this generation has the desire to engage in new experiences and opportunities to meet people. This behavior can be used to offer a craft product with the addition of experience and stories that can attract millennials. Located in Kemang, which is known as an area that developed towards the artpreneur with the presence of various art store and galleries. This studio provides a space for experience seekers and creative industry players to share ideas, products, knowledge, and tools. The objective is so that those who do not have the skills yet can gain new experiences and skills, even explore the potential in the creative industry. As for creative economic actors, they can deepen their potential and share their knowledge. Aside from that, they can also market their products to a wider scope.
\end{abstract}

Keywords: creative; creative economy; experience; millenials; woodcrafts 


\section{PENDAHULUAN}

\section{Latar Belakang}

Generasi millenial memiliki kreatifitas yang tinggi, mereka cenderung kritis dan sangat menghargai otentitas, sehingga banyak menghasilkan inovasi dan kreasi baru. Ditandai dengan berkembangnya ekonomi kreatif di Indonesia. Menurut data dari Badan Pusat Statistik, ekonomi kreatif menyumbang sekitar $11 \%$ dalam perekonomian Indonesia. Hal ini turut didorong oleh teknologi, seperti media sosial. Tidak di pungkiri media sosial sangat memberikan potensi besar bagi pelaku ekonomi kreatif.

Terdapat tiga subsektor terbesar diantara 16 subsektor lain, salah satunya adalah subsektor kerajinan atau kriya. Menurut Data BEKRAF tahun 2017, kontribusi PDB ekonomi kreatif subsektor krita sebesar $15,7 \%$. Saat ini hadir banyak ekonomi kreatif dibidang kerajinan kayu atau woodcraft . Produk kayu yang dihasilkan tidak hanya berupa furniture tapi juga aksesoris fashion serta hiasan vintage. Hasil woodcraft seperti aksesoris fashion berupa jam tangan, kacamata dan lainnya mulai dikembangkan. Banyak sekali generasi-generasi muda yang mulai menggemari dan mencintai produk-produk kerajinan ini. Kesan vintage, simple dan elegan menjadi alasan bagi mereka menggunakan produk-produk woodcraft.

Hasil kerajinan kayu masih dapat berkembang dengan luas. Saat ini kerajinan kayu sudah memanfaatkan limbah kayu, mulai dari potongan kayu hingga serbuk kayu diubah menjadi barang yang bernilai. Potongan kayu berukuran kecil disulap menjadi aksesoris indah. Serbuk kayu dipadatkan menjadi lembaran gabus kayu, disulap menjadi dompet dan lain-lain.

Menurut Data BPS(2011- 2015) mengenai pertumbuhan ekonomi kreatif di berbagai sektor kerajinan, khususnya kerajinan kayu, barang dari kayu, dan lainnya mengalami pertumbuhan yang stagnan. Adapula kendala yang dihadapi pelaku ekonomi kreatif yang menyebabkan kurang berkembangnya bidang ini, seperti kurangnya fasilitas untuk riset dan pengembangan , terbatasnya fasilitas peralatan bagi pelaku. Selain itu kendala promosi dalam negeri, padahal minat kerajinan kayu dari luar negeri tinggi. BEKRAF memberi perhatian khusus pada kerajinan kayu, karena potensi kayu yang besar didalam maupun luar negeri.

Untuk mendorong pertumbuhannya, khususnya pada generasi ini, salah satu cara yang dapat digunakan, dengan memberikan pengalaman. Memberikan pengalaman mengenai cara membuat maupun prosesnya, merupakan salah satu cara untuk mengenalkan kerajinan pada generasi ini. Pengalaman yang ditawarkan dapat berupa pengalaman membuat, kegiatan workshop ,pengalaman melihat proses pembuatan produk, serta kegiatan promosi.

Kegiatan workshop diminati dalam kurun waktu beberapa tahun ini, pengalaman membuat dan memberikan ilmu (skill), disertai dengan pengalaman sosial untuk berinteraksi dan bertemu komunitas. Platform edukasi Mau Belajar Apa, plaform yang mempertemukan orang-orang yang punya passion untuk sharing dan berbagi ilmunya dengan orang banyak dengan orang-orang yang mencari ilmu (skill). Jourdan Kamal selaku CEO MauBelajarApa, menyatakan bahwa dalam waktu 2 tahun (2015-2017), platform ini telah berhasil mengelola penjualan kelas lebih dari 1.000 workshop dan dipakai 10.000 pengguna.

Hal ini didukung karena generasi millennial memiliki perilaku yang berdeda dari generasi sebelumnya, salah satu perilaku yang berubah adalah pola konsumsi. Generasi millennial adalah konsumen yang haus akan pengalaman (experience) dibandingkan dengan generasi sebelumnya. Survei Everbrite-Harris Poll (2014) menyatakan bahwa millennial lebih memilih menghabiskan uang untuk pengalaman dibandingkan barang. Tidak seperti generasi sebelumnya, yang hanya berusaha untuk memenuhi kebutuhan dasar, generasi millennial berusaha untuk menunjukan suatu prestasi atau pengalaman yang mereka lakukan untuk mendapatkan pengakuan (esteem). Generasi millennial berkeinginan untuk mampu melakukan hal-hal yang baru.

Menurut Abraham Maslow(1943),saat kebutuhan dasar sudah terpenuhi maka, kebutuhan manusia akan naik ke tingkat selanjutnya, yaitu kebutuhan psikologis. Kebutuhan psikologis berupa kebutuhan sosial dan melibatkan perasaan memiliki. Pada tingkatan selanjutnya 
terdapat kebutuhan harga diri (esteem). Harga diri dapat berupa martabat, prestasi, penguasaan, dan prestise. Ketika generasi millennial merasakan suatu pengalaman, Kebutuhan psikologisnya akan terpenuhi. Pemenuhan kebutuhan psikologis dapat berupa pengalaman dengan komunitas, hobi, dan kegiatan yang melibatkan skill.

Dengan melihat perubahan perilaku generasi millennial yang kreatif, inovatif, selalu mencari experience baru. Memberikan pengalaman dapat mendorong pertumbuhan dan minat pada ekonomi kreatif bidang kerajinan. Maka itu, diperlukannya wadah dimana, para pencari experience dan pelaku industri kreatif bisa sharing ide, produk, ilmu, dan alat. Sehingga yang belum memiliki skill bisa mendapatkan pengalaman dan skill baru, bahkan membantu menggali potensi dan memulai usaha dibidang industri kreatif. Sedangkan untuk para pelaku ekonomi kreatif, dapat memperdalam potensi yang ada dan sharing ilmu yang mereka punya. Selain itu juga dapat memasarkan produk mereka ke lingkup yang lebih luas.

\section{Identifikasi Masalah}

Berdasarkan latar belakang diatas, maka permasalahan yang muncul untuk mewujudkan program arsitektural, yaitu:

a. Dibutuhkan wadah untuk mendorong pertumbuhan ekonomi kreatif khususnya dibidang kerajinan dalam memfasilitasi promosi dan pengembangan.

b. Dibutuhkan wadah yang dapat memfasilitasi generasi millennial untuk mendapatkan pengalaman, terutama yang bersifat edukasi sekaligus rekreatif.

c. Belum tersedianya wadah untuk menjadi sarana dan memfasilitasi peminat workshop untuk dapat belajar dan memfasilitasi kegiatan riset dan pengembangan bagi penggiat industri kreatif maupun masyarakat umum.

\section{Rumusan Masalah}

a. Program apa saja yang cocok untuk mendorong minat dan potensi generasi millennial terhadap ekonomi kerajinan khususnya di bidang kerajinan?

b. Bagaimana mewujudkan wadah yang dapat meningkatkan kreatifitas dan potensi generasi millennial?

\section{Batasan dan Sasaran Proyek}

Proyek sebagai fasilitas untuk mendorong pertumbuhan ekonomi kreatif khususnya bidang kerajinan dengan menyediakan sarana pendidikan non-formal dan juga wadah kegiatan sharing skill/ pengembangan kemampuan untuk mendapatkan pengalaman. Selain itu, proyek juga menjadi wadah promosi dan apresiasi terhadap ekonomi kreatif kerajinan, berupa pameran dan penjualan produk. Produk ekonomi kreatif yang dihasilkan berupa hasil kerajinan, dengan mengolah bahan baku utama,kayu dan limbah kayu. Proyek memiliki sasaran untuk pelaku ekonomi kreatif dibidang kerajinan maupun masyarakat umum yang memiliki ketertarikan dan minat terhadap seni, serta cara dan prosesnnya

\section{Tujuan Proyek}

Proyek ini memiliki tujuan menjadi wadah dan fasilitas bagi para pengrajin ataupun peminat ilmu dan proses kerajinan tangan, Selain itu juga, bertujuan untuk mendorong dan memelihara pertumbuhan ekonomi kreatif kerajinan kayu dengan mengangkat dan memasarkan hasil kerajinan tangan.

\section{KAJIAN LITERATUR}

\section{Generasi Millenial}

Milenial adalah kelompok demografi setelah Generasi X . Lahir pada rentang tahun 19802000an. Generasi ini jumlah populasinya yang tengah berada diusia produktif dan memiliki 
jumlah terbesar secara global. Menurut data Badan Pusat Statistik(BPS) tahun 2016, jumlah generasi millennial di Indonesia mencapai 34\% dari total penduduk Indonesia.

Generasi ini memiliki perilaku yang berbeda dari generasi sebelumnya, salah satunya adalah perilaku konsumtif. Ada yang dinamakan dengan konsep experimental consumption yang dikenalkan oleh Holbrool dan Hirschman, dimana ketika mengkonsumsi suatu hal, ada dimensi aktivitas yang menyenangkan, kesenangan indra, kenikmatan estetik dan respons emosional. Konsumsi melibatkan aliran fantasi, perasan, dan kesenangan yanag berlanjut ke experimental view. (Mix Marcomm, 2018)Menurut survey Evenbrite(2014) 78\% uang generasi millennial dibelanjakan untuk terlibat pengalaman baru. $82 \%$ mengikuti berbagai pengalaman langsung, seperti lomba, konser, dan lainnya.

Selain itu, menurut survei PEW Research Center(2010),Generasi millennial disebut 6\% lebih pintar dari generasi sebelumnya. Generasi ini memiliki rasa ingin tahu yang tinggi, bahkan cenderung kritis. Karakter ini yang mendukung generasi ini rajin mencari tahu tentang banyak hal. Generasi ini juga disebut memiliki edukasi yang lebiih tinggi dari generasi sebelumnya. Mereka juga kreatif, karena berpikir secara kritis, sehingga mampu memberikan gagasan/ solusi terhadap permasalahan yang ada.

Millennial tumbuh dalam budaya berbagi (sharing economy). Majalah Forbes menyebutnya fenomena ini sebagai NOwnership. Dalam artikel 'NOwnership, No Problem: Why Millennials Value Experiences Over Owning Things' (Blake Morgan, 2015) yang terdapat disitus forbes.com menyebutkan bahwa generasi muda tampaknya memiliki suatu pandangan membeli barang tidak memiliki nilai yang sama untuk generasi millenial seperti yang terjadi pada orang tua atau kakek nenek mereka. Karena pandangan itulah yang membuat generasi millennial lebih memilih untuk sharing daripada kepemilikan.

\section{Hierarki Kebutuhan Manusia Menurut Abraham Maslow}

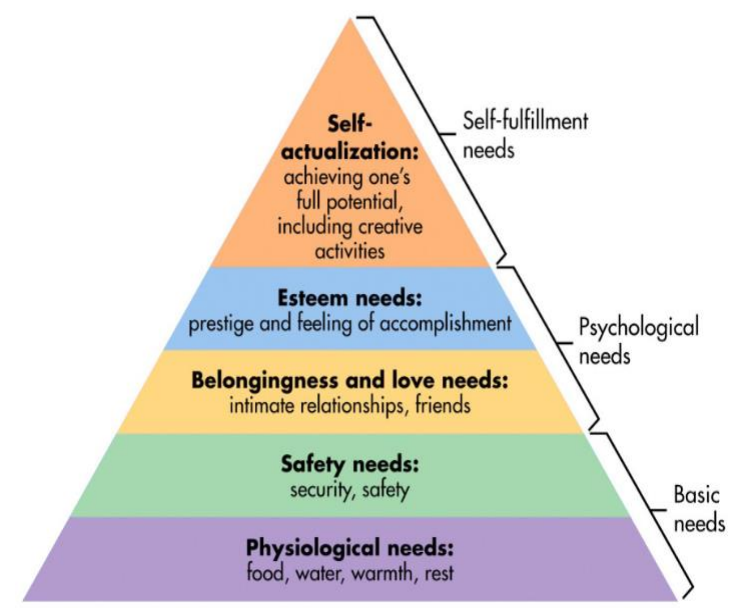

Gambar 1. Piramida Kebutuhan Manusia

Sumber: https://www.simplypsychology.org/maslow.html

Maslow (1943) menemukan bahwa motif manusia didorong oleh hasrat untuk memenuhi kebutuhan, dimulai dari yang paling dasar sampai kebutuhan-kebutuhan khusus bila yang dibawahnya sudah dipenuhi. Saat kebutuhan dasar sudah terpenuhi maka, kebutuhan manusia akan naik ke tingkat selanjutnya. Kebutuhan manusia dibagi maslow menjadi 3 kategori yaitu:

a. 'Basic Needs' atau Kebutuhan Dasar

b. Kebutuhan Psikologi

c. Kebutuhan Pemenuhan Diri.

\section{Ekonomi Kreatif Kerajinan}

Dalam Rencana Nasional Badan Ekonomi Kreatif Kerajinan, disebutkan bahwa kerajinan sebagai salah satu subsektor dalam ekonomi kreatif, karena kerajinan berbasis kepada ide dari 
daya kreativitas seseorang akan pengetahuan, warisan budaya, dan juga teknologi yang diketahuinya.

Kata "kerajinan" dalam bahasa Inggris, adalah "craft" yang merupakan serapan dari bahasa Jerman, kata ini memiliki arti "kekuasaan, kekuatan fisik, keahlian". Hadir juga dalam bahasa Belanda, yaitu "kracht" dan juga bahasa Swedia "kraft" yang memilki arti "kekuatan". Kata "craft" ini kemudian dalam bahasa Inggris berkembang dalam pemahamannya, yaitu dari "keahlian, seni, ilmu dan talenta", hingga ke "perdagangan, kerajinan tangan, panggilan" dan "sesuatu yang dibuat atau dibangun".

Kata "kerajinan" berasal dari kata "rajin" yang berarti suka bekerja, getol, dan sungguhsungguh bekerja. la mendapatkan awalan "ke" dan akhiran "an" yang kemudian menjadi kata benda yang berarti barang yang dihasilkan melalui keterampilan tangan seperti tikar, anyaman, gerabah, dan sebagainya. Selain itu, ada juga istilah yang sering dipakai untuk kata kerajinan, yaitu "kriya". Kata ini memiliki arti pekerjaan (kerajinan) tangan.

Kerajinan diklasifikasikan seperti gambar dibawah ini. .

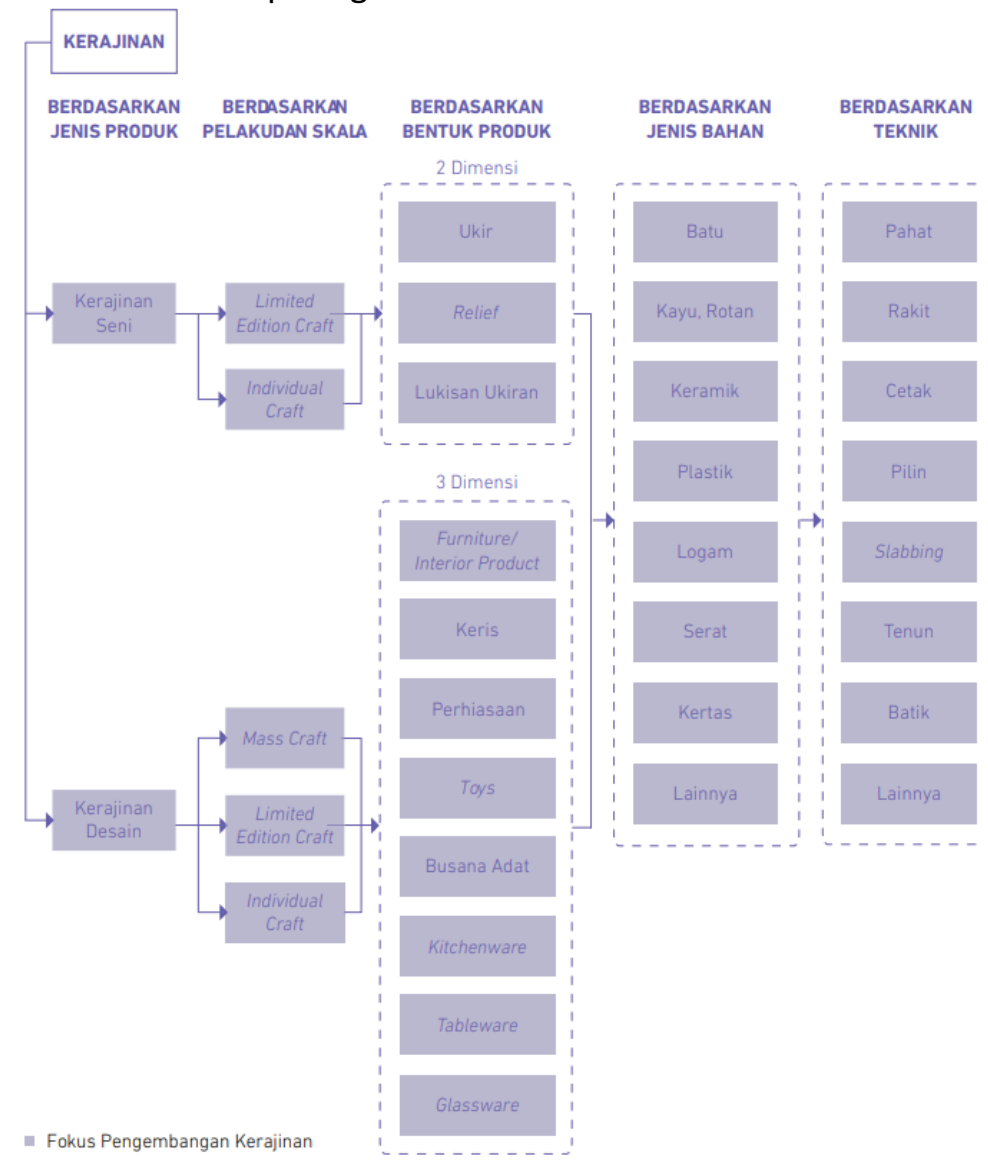

Gambar 2. Klasifikasi Barang Kerajinan Sumber: Badan Ekonomi Kreatif, 2018

Salah satu upaya memahami dan mengenal industri ekonomi kreatif, dengan menggunakan pemetaan ekosistem . yang memberikan gambaran menyeluruh kondisi ideal dari ekosistem kerajinan. Gambaran menyeluruh ini berdasarkan pada hasil kajian yang sudah dilakukan oleh BEKRAF, dan diharapkan dapat menjadi kenyataaan bagi industri kreatif di Indonesia, khususnya subsektor kerajinan. Dalam Ekosistem secara umum merupakan suatu tatanan kesatuan secara utuh dan menyeluruh antara segenap komponen yang saling mempengaruhi. Di dalam ekosistem ini terdapat keterkaitan antar komponen yang menggambarkan aktivitas di setiap tahapan kreatif dan peran pelaku utama yang terlibat di dalamnya. 
Adapun komponen-komponen utama dalam peta ekosistem kerajinan adalah:

a. Rantai nilai kreatif (creative value chain) : pada bagian ini terdapat proses penciptaan ide, produksi, distribusi, serta promosi.

b. Lingkungan pengembangan (nurturance environment): lingkungan pengembangan berupa pelatihan dan Pendidikan secara formal dan non-formal, serta apresiasi. Apresiasi memiliki tujuan untuk memberikan pengakuran dan penghargaan terhadap pelaku-pelaku di subsektor kerajinan.

c. Pasar (market) : bagian ini menjelaskan pihak-pihak yang menjadi pembeli dari barangbarang kerajinan.Pasar yang dimaksudkan disini tidak hanya pihak yang membeli, tetapi juga pihak yang menggunakan atau menkonsumsi barang-barang kerajinan

d. Pengarsipan (archiving) : merupakan proses dokumentasi dan penyimpanan karya atau catatan mengenai kerajinan tertentu.

\section{Sejarah dan Perkemabangan Workshop}

Workshop sendiri sudah ada sejak zaman logam. Pada tahun 1974, sebuah ekspedisi yang dilakukan di sungai Ciliwung menemukan peralatan yang dipakai untuk membuat kapak perunggu, benda ini diperkirakan berasal dari tahun 1000-500 tahun sebelum Masehi. Bukti penemuan peralatan tersebut menjadi salah satu awal pembangunan peradaban yang kita kenal saat ini.

Sejak Revolusi Industri dimulai di awal abad ke-19, Pabrik-pabrik besar untuk produksi skala besar dibuat. Workshop menjadi sebuah ruang atau bangunan yang menyediakan ruang dan peralatan termasuk mesin yang dibutuhkan dalam proses fabrikasi. Sedangkan di abad 2021 , banyak rumah barat yang memiliki sebuah workshop di garasi ataupun basement. Biasanya berisi berbagai macam peralatan rumahan, seperti hand tools, power tools, dan sebagainya. Tak hanya untuk pribadi, namun juga dijual dalam bentuk jasa. (Flaherty:2012)

Semakin berkembangnya zaman, semakin banyak orang yang mencoba membuat sesuatu. Semakin banyak pula orang-orang membutuhkan peralatan, ruangan dan ilmu untuk "making something". Tuntutan akses ke peralatan dan mesin-mesin memulai munculnya gerakan "makermovement". 'maker movement' adalah bangkitnya ketertarikan dalam membuat benda fisik dengan peralatan digital dan perencanaan dan teknik dari Internet (Burke, 2014, p. 11)

Makerspace adalah sebuah pusat komunitas yang menyediakan teknologi, peralatan fabrikasi dan kesempatan pendidikan kepada publik. Makerspace sendiri sebenarnya muncul pada tahun 2005. Pertama kali digunakan oleh MAKE magazine dan menjadi populer di awal 2011, ketika MAKE magazine membuka tempat tersebut untuk diakses publik.

Makerspace merupakan tempat di mana orang-orang kreatif dapat berkumpul, berkreasi, menciptakan, dan belajar bersama. Di dalam makerspace, pengguna perpustakaan mempunyai akses untuk menggunakan printer 3D, peralatan audio visual, laser pemotong dan pengukir, mesin jahit, kamera dan peralatan lain, baik perangkat keras (hardware) maupun perangkat lunak (software) yang dapat digunakan secara gratis untuk menciptakan/mewujudkan banyak hal berdasarkan apa yang dibayangkan.

Heridan(2014) menuturkan bahwa "ruang membuat dan desain kolaboratif dan kegiatan yang mereka dukung telah menghasilkan minat dalam beragam bidang pendidikan" (hal. 506). Sebagai contoh, banyak museum, perpustakaan, dan sekolah telah secara tegas merangkul ruang pembuat dan pembelajaran sebagai bagian dari program pendidikan mereka.

\section{METODE}

Metode secara umum perancangan Studio Kreatif dan Inovasi Kerajinan Kayu menggunakan metode observasi, analisa, dan sintesa untuk menjelaskan permasalahan serta mengetahui perilaku generasi millennial dan kebutuhannya serta diidentifikasi untuk kemudian setelah itu dilakukan sintesis dan analisis. Tahap pengumpulan data cukup beragam 
sumbernya dengan menyesuaikan kebutuhan akan penggunaan data tersebut. Pengumpulan data dibagi secara bertahap sehingga maksud dan tujuan penggunaan data lebih jelas dengan disertakan sumbernya. Pada tahap analisa bertujuan untuk mendefinisikan program yang dibutuhkan dan pada tahap sintesa merupakan hasil dari analisa yang dilakukan.

\section{DISKUSI DAN HASIL \\ Program}

Tujuan utama proyek ini mewadahi kegiatan dan proses kreatif yang mendorong dan memelihara perkembangan ekonomi kreatif dibidang kerajinan. Untuk menentukan program maka perlulah membangun ekosistem ekonomi kerajinan yang sesuai.

Penentuan program dan aktivitas didasari oleh tujuan yang ingin dicapai, yakni menjadi wadah dan fasilitas edukasi dan rekreatif bagi para pengrajin ataupun peminat ilmu dan proses kerajinan tangan, serta sarana pemasaran.

\section{Tinjauan Lokasi}

Jakarta Selatan merupakan daerah yang memiliki paling banyak pusat kegiatan, mulai dari restoran, café, hiburan malam, hingga galeri seni. Pusat aktivitas hiburan tersebar di Jakarta Selatan, karena Jakarta Selatan memiliki banyak Kawasan Hunian, dengan mayoritas penduduk memiliki kelas ekonomi menengah keatas.

Fasilitas-fasilitas yang terdapat pada daerah Jakarta Selatan berlomba untuk menampilkan karya produk atau tempat kreatif guna untuk menarik pengunjung. Selain itu, Jakarta Selatan menjadi tempat yang paling banyak memiliki vendor /brand kreatif yang menyelenggarakan workshop untuk sharing ilmu dan skill.

Komunitas muda kreatif menghadirkan banyak toko brand lokal. Brand lokal tersebar di wilayah Blok $\mathrm{M}$ hingga Kemang. Daerah Kemang seringkali disebut sebagai Urban Culture Life Style. Sejak tahun 1980-an , karena kawasan ini telah dikenal sebagai tempat berkumpulnya banyak komunitas. Mulai dari restoran, café, galeri, hingga hiburan malam ada di kawasan ini. Daerah Kemang dekat dengan wilayah pemukiman kelas menengah keatas, menjadikan wilayah ini dilengkapi berbagai fasilitas yang menunjang hunian di sekitarrnya. Selain itu, bisnis pada wilayah Kemang yang berkembang kearah artpreneur, dengan hadirnya berbagai craft/ art store, galeri, butik, dan lain-lain.

Muncul banyak toko-toko local brand, seperti distro, etnic store, dan toko kesenian, sehingga karakter kawasan terlihat menuju ke pengembangan hobi dan kesenian. Kawasan Kemang memiliki potensi untuk berkembang kearah hobi dan industri kreatif dan bersifat edutainment. Penduduk pada kawasan ini juga didominasi oleh generasi millenial, sehingga proyek ditujukan khususnya untuk generasi millenial.

Tabel 1 :Jumlah Penduduk Berdasarkan Usia di Kelurahan Bangka dan Pela Mampang

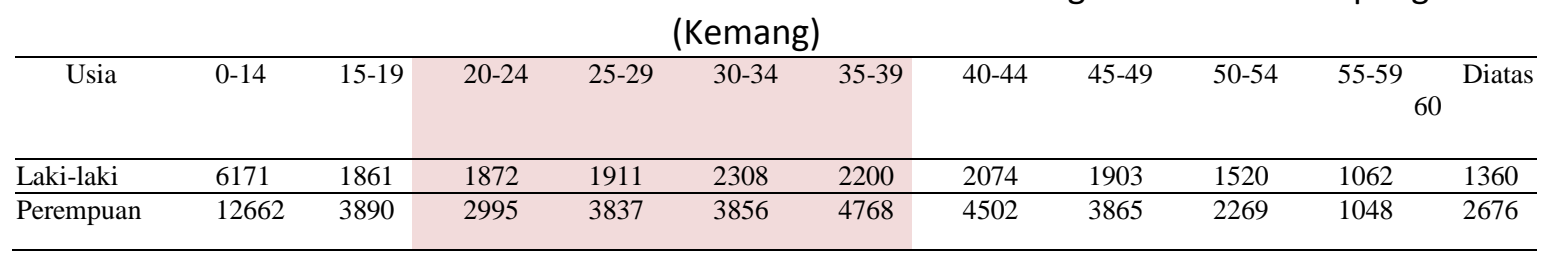

Sumber: Jakartasmartcity.go.id 


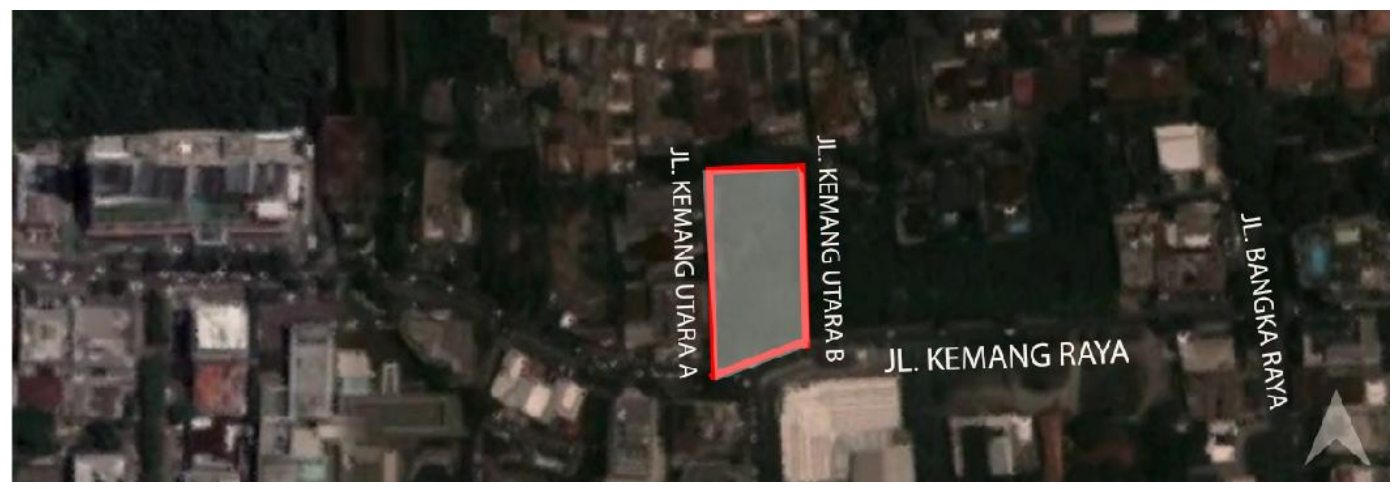

Gambar 3. Tapak

Sumber : google maps

Tapak terletak di Jalan Kemang Raya dan diapit 4 sisi jalan. Luas tyapak $4060 \mathrm{~m}^{2}$ dengan KDB 50\% dan KDH 30\%. Berada pada zona perdagangan dan jasa.

Kelebihan tapak :

- Terletak di wilayah yang ramai dan dekat dengan transportasi umum bus pengumpan.

- Terletak dijalan yang ramai dan jalur utama yang menghubungkan Jalan Kemang Raya dengan Jalan Bangka

- Memiliki jalur pedestrian yang cukup baik

- Keempat sisi diapit oleh jalan

Kekurangan pada tapak sering terjadi kemacetan di Jalan Kemang Raya, terutama pada persimpangan dari Jalan Kemang 1 ke Jalan Kemang Raya.

\section{Peluang :}

-Berada di wilayah yang dapat ditempuh dengan berjalan kaki dari pertokoan dan hunian sekitar, sehingga dapat mengundang pejalan kaki datang ke tapak, disertai jalur pedestrian dengan keadaan yang cukup baik.

- Keadaan sekitar tapak yang ramai dan banyak aktivitas, menjadi daya tarik dan pendukung untuk pengunjung datang ke tapak

Sirkulasi pada kawasan terjadi pengalihan arus di Jalan Kemang Raya menjadi satu arah. Sehingga kendaraan harus memutar di Jalan Kemang 1. Sirkulasi kendaraan menuju bangunan dapat melalui Jalan Kemang Utara B dan keluar pada Jalan Kemang Utara A, sehingga untuk kendaraan yang menuju Jalan Pangeran Antasari , tidak perlu memutar ke Jalan Kemang 1

Tapak diapit oleh empat sisi jalan, dengan satu jalan utama, dan 3 jalan lingkungan. Bangunan disekitar tapak didominasi oleh bangunan komersil berupa tempat kegiatan serta hiburan. Sehingga sepanjang jalan kemang raya dapat membentuk satu jalur pedestrian yang mebnghubungkan antara bangunan dikawasan. Sehingga bangunan dapat dibuat berorientasi pada pejalan kaki. 


\section{Konsep Desain}

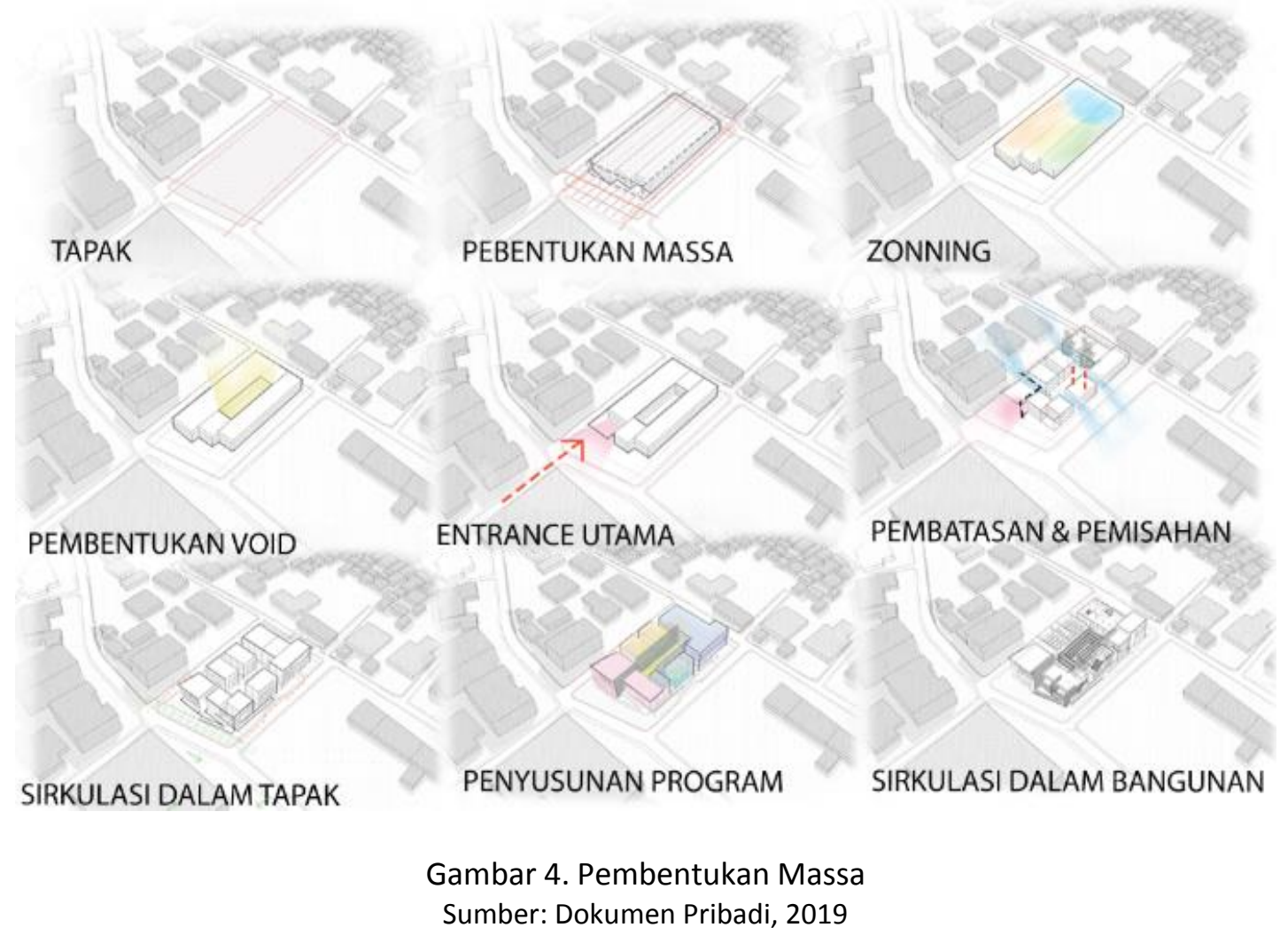

Pembentukan massa dengan mengikuti bentuk tapak untuk kemudian pada bagian yang miring massa dimundurkan menjadi 3 bagian sehingga membentuk kemiringan yang sama. Kemudian pembagian zoning dibentuk berdasarkan lingkungan ekosistem kerajinan, yaitu area promosi dan pengarsipan, area pengembangan dan kelas, area proses kreatif, dan area berkumpul.

Pembentukan void pada bagian tengah massa sehingga cahaya dan udara dapat masuk kedalam dan pada bagian tersebut dijadikan area berkumpul (gathering zone). Kemudian entrance diletakan sejajar dengan jalan yang berada di depan tapak, selain itu pada bagian tersebut juga merupakan salah satu nodes kawasan, sehingga i utama menjadi bagian yang menangkap pengunjung dari dua arah.

Entrance utama yang dibentuk dibatasi dan pisahkan sehingga tidak menerus hingga kedalam bangunan pembatasan dengan memberikan vegetasi dan juga dinding.

Sirkulasi dalam tapak terjadi karena tapak diapit oleh empat jalan dengan jalan utama pada bagian muka bangunan diberikan untuk pejalan kaki , dan terdapat entrance lain dari dua sisi samping bangunan. Dan untuk sisi belakang bangunan digunakan untuk sirkulasi service.

Proyek ini memiliki pengelopokan program sesuai dengan tahapan-tahapan yang alami pengunjung ketika melakukan aktivitas didalamnya. Pengelompokan tersebut adalah sebagai berikut.

Program tersebut disusun sebagai tahapan-tahapan bagi pengunjung yang beraktivitas di proyek ini. Yang pertama adalah tahap Experience\&Llearn, dimana menawarkan kegiatan yang menawarkan pengalaman dan kegiatan pengenalan kepada publik. Sedangkan Explore merupakan program lanjutan yang merupakan kegiatan pembelajaran mengenai kerajinan kayu. Untuk program Develop merupakan program yang memberikan fasilitas untuk pelaku ekonomi kreatif lebih mengembangkan dan memperluas kemampuannya.

Dalam program Community terdapat berbagai kegiatan yang bertujuan untuk memperluas dan mengenalkan berbagai kerajinan pada masyarakat, serta memperluas kemungkinan adanya kolaborasi. 


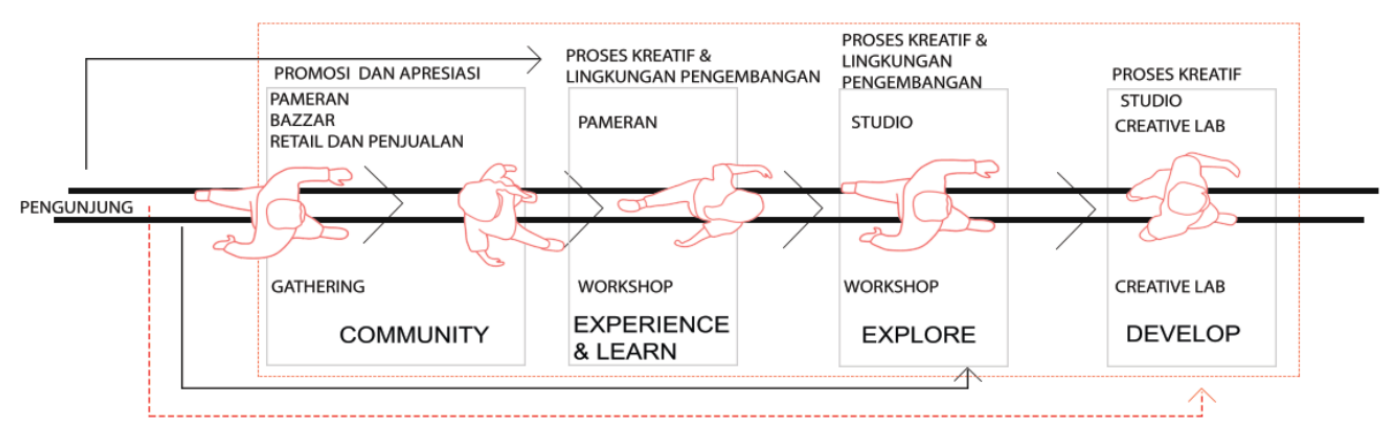

Gambar 5. Tahapan-Tahapan Program

Sumber: Penulis, 2019

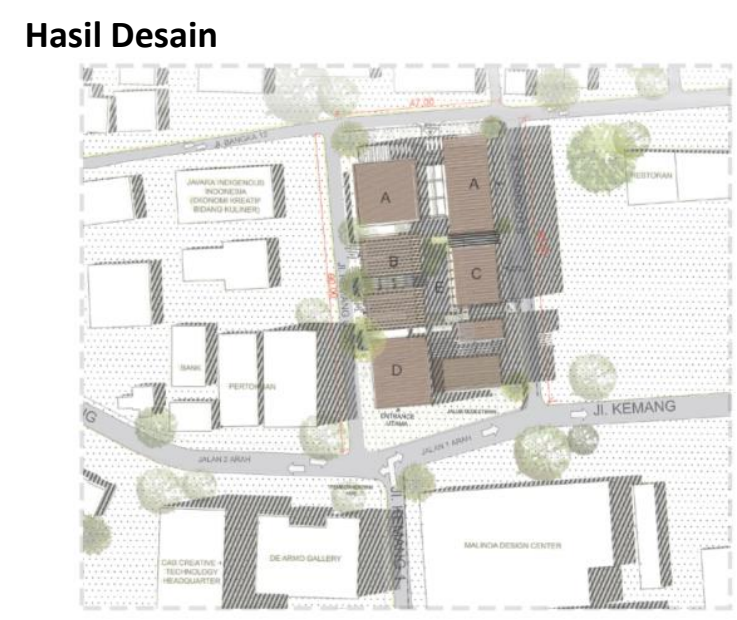

A- AREA PROSES KREATIF

B- AREA PEMASARAN \& PENGARSIPAN

C- AREA PELATIHAN \& PENGEMBANGAN

D- ENTRANCE HALL

E-TAMAN (COURTYARD)

Gambar 6. Block Plan

Sumber: Penulis, 2019

Entrance utama terbuka menerus ke arah sisi Jalan Kemang 1, diharapkan dapat menerima pengunjung dan sebagai penangkap visual dari luar ke dalam tapak.

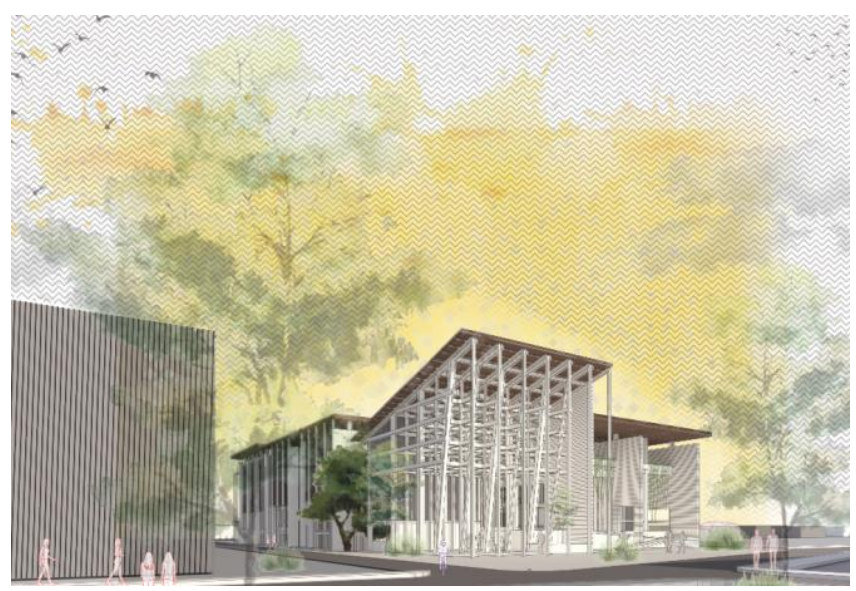

Gambar 7. Perspektif Eksterior

Sumber: Penulis, 2019

Pada lantai semi basement merupakan parkir kendaraan bermotor, area servis, dan kantor pengelola. Pada lantai ini terdapat hall bazaar yang terkoneksi langsung ke pedestrian, serta taman. Taman (courtyard) dapat digunakan sebagi pelebaran dari hall bazzar ataupun pameran sementara. Taman juga dapat digunakan untuk kegiatan event seperti workshop dan juga talkshow ataupun seminar terbuka. 
Pada lantai dasar terdapat program retail(pemasaran dan penjualan), area proses kayu, dan juga area experience/ workshop dan kelas beserta dengan retail material. Pada lantai ini juga terdapat program penunjang seperti coffee shop.
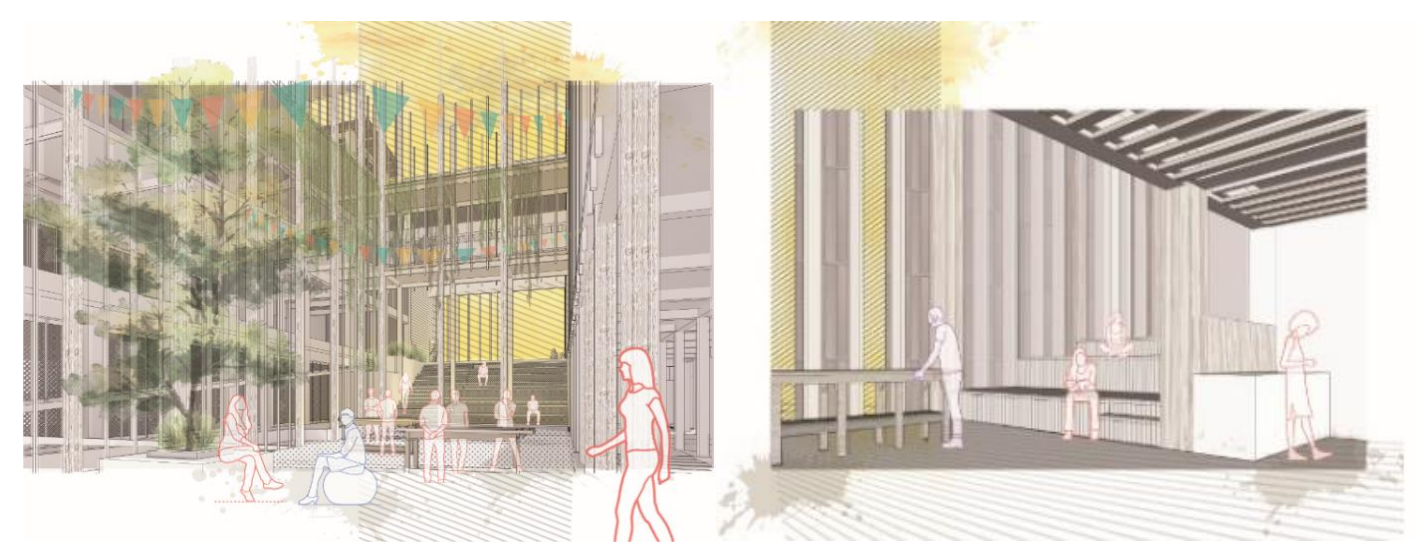

Gambar 8. Perspektif Suasana Taman (Courtyard) dan Studio Sumber: Penulis, 2019

Studio yang terdapat pada lantai dua merupakan studio yang dapat digunakan secara bersama-sama, pengunjung bebas memilih meja yang akan digunakan. Pada area ini disediakan berbagai kebutuhan dan peralatan untuk membuat kerajinan kayu. Pada lantai dua jug terdapat galeri dan pameran kerajinan kayu, serta terdapat ruang buku material.
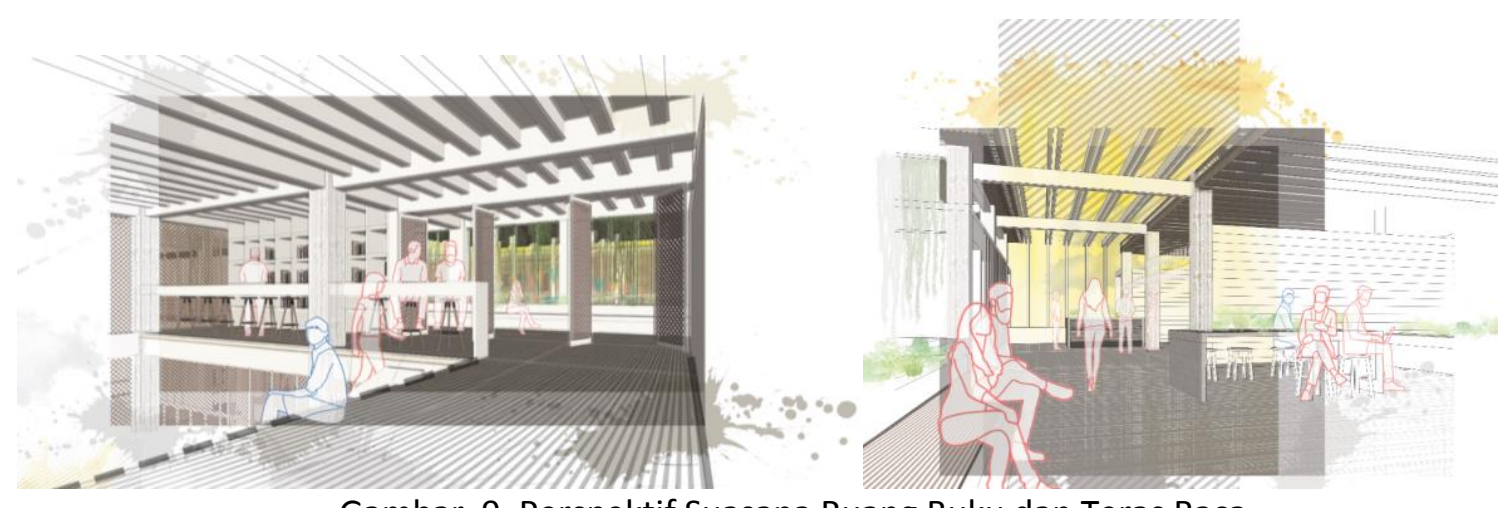

Gambar 9. Perspektif Suasana Ruang Buku dan Teras Baca Sumber: Penulis, 2019

Pada lantai tiga terdapat program rental studio, yang dapat disewa untuk mengerjakan berbagai produk kerajinan kayu. Pada lantai ini terdapat ruang baca serta ruang kerja dan kelas daur ulang kertas yang terkoneksi langsung dengan teras.

Lantai empat merupakan teras (roof top) yang dapat digunakan untuk acara komunitas ataupun outdoor activity, seperti membuat daur ulang kertas ataupun kompos. Pada lantai ini juga digunakan sebagai area penanaman bibit pohon kayu, yang digunakan untuk tujuan edukasi. 


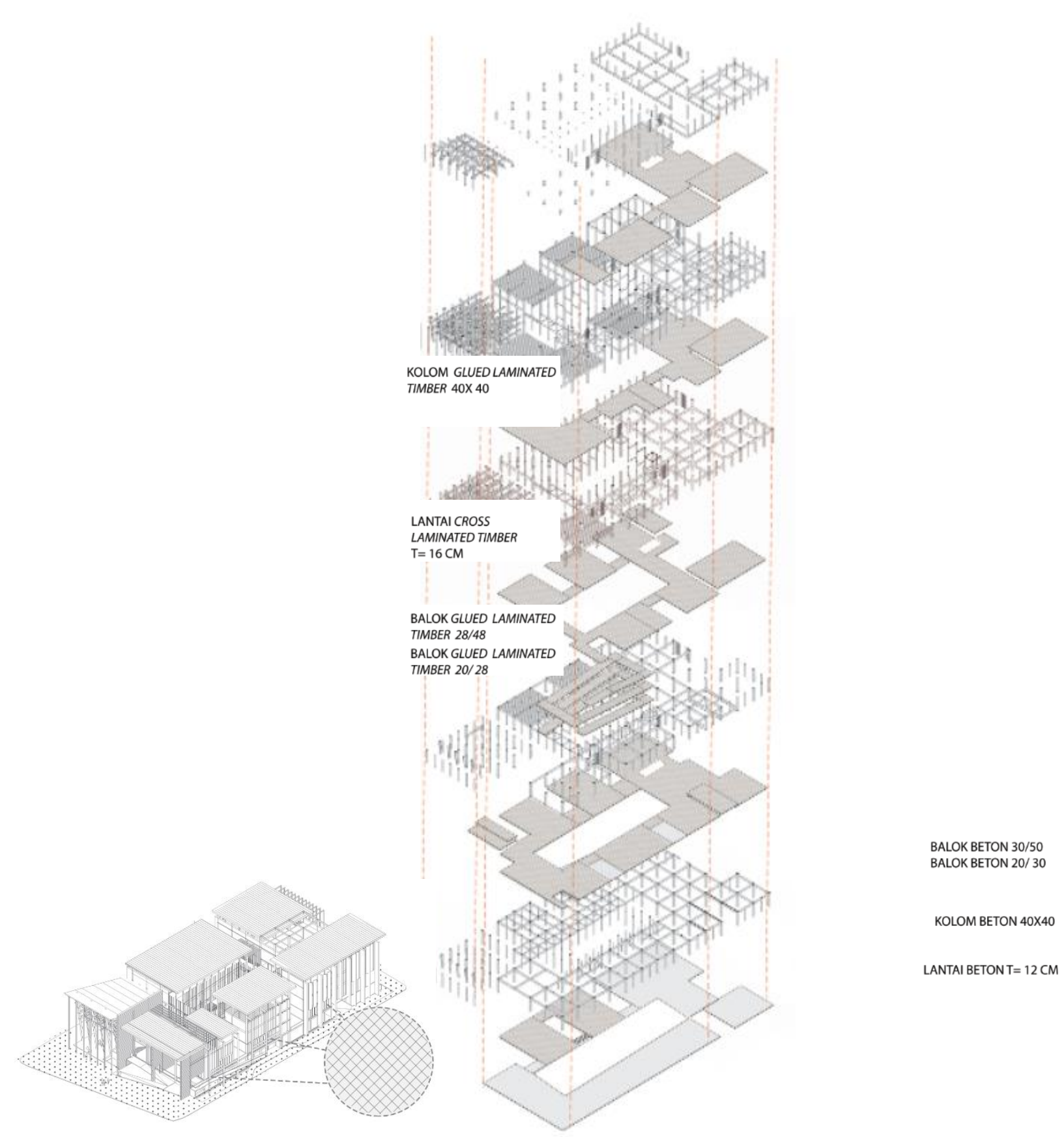

Gambar 10. Penggunaan Material dan Struktur Lantai, Kolom , dan Balok Sumber: Penulis, 2019

Struktur yang digunakan untuk proyek ini didominasi dengan penggunaan kayu. Penggunaan kayu dilakukan untuk memberi citra bangunan yang sesuai dengan program yang ada dalam bangunan. Terutama pada bagian entrance hall, dimana terdapat kolom-kolom kayu. Kolom-kolom tersebut memiliki fungsi untuk mengarahkan sirkulasi, pada ruang antar kolom dapat digunakan untuk meletakan display dan pameran sementara. Selain itu juga, kolom-kolom pada entrance hall menjadi focal point pada bangunan ini.

Penggunaan material untuk fasad didominasi oleh papan kayu dan kisi-kisi kayu. Kayu yang digunakan untuk fasad merupakan kayu-kayu bekas. Untuk fasad bangunan juga menggunakan wire mess, karena dengan menggunakan material ini, udara dapat masuk kedalam bangunan. Sehingga penggunaan pengudaraan buatan dapat diminimalisir. 


\section{KESIMPULAN DAN SARAN}

\section{Kesimpulan}

Generasi millenial memiliki perilaku yang berbeda, generasi ini menikmati proses ataupun kegiatan yang memberikan pengalaman dan kesempatan bertemu orang baru. Salah satu cara untuk menarik minat dan perhatian generasi ini adalah dengan kegiatan pengalaman seperti workshop dan berbagi ilmu. Studio Inovasi dan Kreatif Kerajinan Kayu ini hadir untuk mengenalkan dan menjadi wadah yang menyediakan sumber daya, fasilitas, pengetahuan, dan pemasaran sehingga dapat turut mendorong dan memelihara pertumbuhan ekonomi kreatif khususnya kerajinan kayu dalam masyarakat.

\section{Saran}

Dalam proses perancangan perlu meneliti atau melakukan riset dan mencari data tentang isu yang ingin diangkat. Setelah itu menentukan lokasi dan program yang sesuai dengan konteks isu yang diangkat. Untuk menanggapi isu dan tema mengenai generasi millennial, maka perlu melakukan kajian dan riset mengenai generasi ini, sehingga dapat menentukan program yang sesuai dengan perilaku generasi millennial.

\section{REFERENSI}

Admin. (2012). Arsitektur dan Psikologi. Diakses 23 Desember 2018 melalui blog: http://fansbuku.blogspot.com/2012/01/arsitektur-dan-psikologi.html?m=1

Aiken, M. (2016). The cyber effect: A pioneering cyber-psychologist explains how human behavior changes online. Spiegel \& Grau.

Ahmadi, A.(2018). Walnut - Kayu Gelap Yang Keras, Awet dan Cocok Untuk Kerajinan. Diakses 15 Februari 2019 melalui https://asyraafahmadi.com/in/pengetahuan/material/alami/nontambang/kayu/walnut/

Ahmadi, A.(2018). Cek Dulu Artikel Ini Sebelum Anda Mulai Mengelola Limbah Kayu. Diakses 1 Maret 2019 melalui https://asyraafahmadi.com/in/pengetahuan/ material/alami/nontambang/kayu/pemanfaatan-limbah-kayu/

Aswati, A. (2018). 10 Ciri Dasar Generasi Millennial, Kamu Termasuk Gak Nih?. Diakses 2 Januari 2019 melalui https://www.idntimes.com/life/inspiration/sinta-wijayanti-d/10-ciridasar-generasi-millennial-c1c2/full

Botsman, R., \& Rogers, R. (2010). What's Mine Is Yours-How Collaborative Consumption is Changing the Way we live. Business.

Brett (2018). Brief History of Makerspace Diakses 20 Maret 2019 melalui https://midmomakerlabs.com/brief-history-of-makerspaces/

Kasali, R. (2018). The Great Shifting. Gramedia Pustaka Utama.

Kasali, R. (2016). Ini Beda antara 'Sharing' dan 'Sharing Economy'. Diakses 23 Desember 2018 melalui kompas: https://money.kompas.com/read/2016/05/03/054100826/ Ini.Beda.antara.Sharing.dan.Sharing.Economy.

http://smartcity.jakarta.go.id/maps/, diakses 26 Desember 2018

https://maubelajarapa.com/, diakses 30 Desember 2018

http://www.bekraf.go.id/pustaka/page/data-statistik-dan-hasil-survei-khusus-ekonomi-kreatif, diakses 12 Februari 2019

https://en.oxforddictionaries.com/definition/makerspace, diakses 12 Februari 2018

Madjid, A. (2017). Generasi Milenial dan Keuangan Mereka. Diakses 2 Januari 2019 melalui https://finance.detik.com/perencanaan-keuangan/d-3620868/generasi-milenial-dankeuangan-mereka

Mah, K. (2013). Architecture \& Human Behaviour. Hal 5-8. Diakses 23 Desember 2018 melalui academia.edu

Marcomm, M. (2018). Millenials. Fantasious x Lovable 
McLeod, S. (2018). Maslow's Hierarchy of Needs. Diakses 19 Januari 2019 melalui https://www.simplypsychology.org/maslow.html

Morgan, B. (2015). NOwnership, No Problem: Why Millennials Value Experiences Over Owning Things. $\quad$ Diakses $15 \quad 15 \quad$ Februari $2019 \quad$ melalui https://www.forbes.com/sites/blakemorgan/2015/06/01/nownershipnoproblem-nownersmillennials-value-experiences-over-ownership/\#39d7d7275406

https://id.wikipedia.org/wiki/Workshop, diakses 18 Februari 2019

http://www.raionwood.com/2017/01/kelebihan-memiliki-alat-makan-dan-alat.html, diakses 1 Maret 2019

Laciarsip. (2011). Arsitektur dan Budaya. Diakses 15 Februari 2019 melalui https://www.scribd.com/document/52811565/ARSITEKTUR-dan-BUDAYA

Narjoko,D. , Anas,T., \& Aswicahyono, H.(2015). Rencana Pengembangan Kerajinan Nasional 2015-2019. Jakarta : PT. Republik Solusi, diunduh 21 Maret 2019 melalui http://indonesiakreatif.bekraf.go.id/ikpro/wp-content/uploads/2015/07/RencanaPengembangan-Kerajinan-Nasional.pdf

Purwadi, L. (2016). Indonesia 2020: The Urban Middle Class Millenials. diakses 15 Februari 2019 melalui https://www.researchgate.net/publication/314448735_Indonesia_2020_ The_Urban_Middle_Class_Millenials

Putra, C. N. (2018). Data Statistik dan Hasil Survei Khusus Ekonomi Kreatif. Diakses 20 Maret 2019 melalui http://www.bekraf.go.id/pustaka/page/data-statistik-dan-hasil-survei-khususekonomi-kreatif

Sabdarini, I. T. (2018). Infografis Ringkasan Data Statistik Ekonomi Kreatif Indonesia. Diakses 12 Februari 2019 melalui http://www.bekraf.go.id/berita/page/9/83-infografis-ringkasan-datastatistik-ekonomi-kreatif-indonesia

Slee, T. (2015). What's yours is mine: Against the Sharing Economy. OR Books.

Taher, E. (2017). 4 Karakteristik Millennial yang Perlu Diketahui Bagian Pemasaran. Diakses 18 Januari 2019 melalui https://id.techinasia.com/4-karakteristik-millennial

Tjahjono, G. (2014). Peran Arsitektur dan Antropologi dalam Tata Ruang Kota Indonesia Abad 21. Antropologi Indonesia.

Tsukamoto, Y., \& Kaijima, M. (2010). Behaviorology. Rizzoli International Publications.

Wulandari, D. (2016). Membidik Generasi Millennials. Diakses 23 Desember 2018 melalui https://mix.co.id/mix-magazine/membidik-generasi-millennials 